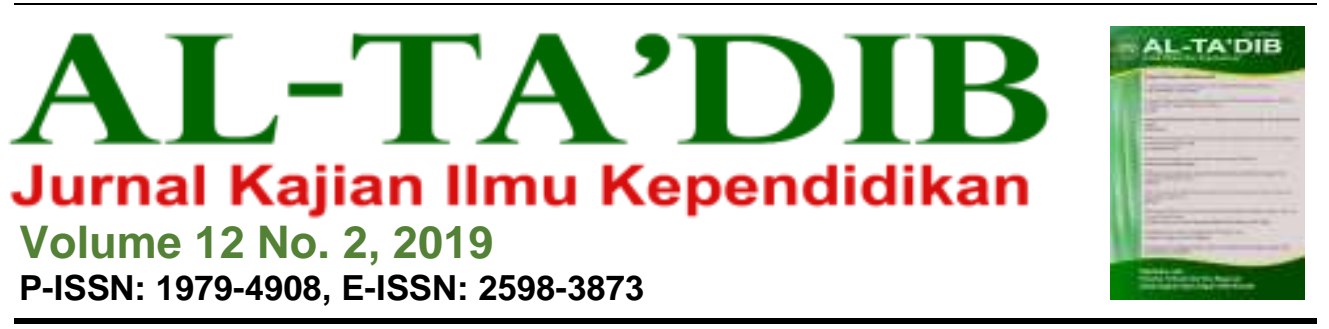

\title{
Efektifitas Penerapan Metode Bermain dengan Media Puzzle dalam Meningkatkan Kemampuan Kognitif Anak
}

\author{
Sitti Aisyah Mu'min', Nova Sarfadillah Yultas ${ }^{2}$ \\ ${ }^{1}$ Institut Agama Islam Negeri Kendari, Indonesia. E-mail: aisyahmumin1972@gmail.com \\ ${ }^{2}$ Institut Agama Islam Negeri Kendari, Indonesia.
}

\begin{tabular}{l} 
INFORMASI ARTIKEL \\
\hline Kata Kunci: \\
Metode bermain; \\
perkembangan kognitif; \\
permainan; puzzle; TK \\
Cara Mensitasi: \\
Mu'min, S. A., \& Yultas, \\
N. S. (2019). Efektifitas \\
Penerapan Metode \\
Bermain dengan Media \\
Puzzle dalam \\
Meningkatkan \\
Kemampuan Kognitif \\
Anak. Al-Ta'dib:Jurnal \\
Kajian Ilmu Kependidikan, \\
12(2), 226-239. \\
DOI: \\
http://dx.doi.org/10.31332/ \\
atdbwv12i2.1217 \\
\hline
\end{tabular}

\begin{abstract}
ABSTRAK
Penelitian tindakan kelas ini bertujuan untuk mengetahui dan mendeskripsikan efektifitas penerapan metode bermain dengan media puzzle dalam meningkatkan kemampuan kognitif pada anak Taman Kanak-Kanak (TK). Dengan instrumen lembar observasi dan penilaian, penelitian ini dilakukan dalam 2 siklus dengan tahapan perencanaan, pelaksanaan, observasi dan refleksi. Hasil data analisis deskriptif menunjukkan bahwa penggunaan media puzzle terbukti efektif meningkatkan kemampuan kognitif anak dengan pencapaian $75 \%$ dari hasil penilaian dan menunjukkan kemampuan minimal berkembang sesuai harapan (BSH). Hasil tes awal menunjukkan bahwa secara klasikal kemampuan anak mencapai $36 \%$ pada kriteria BSH. Setelah tindakan siklus 1, keberhasilan secara klasikal menjadi $55 \%$ dan berada pada kriteria berkembang sangat baik (BSB) dan 45\% BSH. Hasil tindakan setelah siklus 2 menunjukkan perkembangan kognitif anak mengalami peningkatan menjadi $82 \%$ pada kriteria BSH dan $18 \%$ pada kriteria BSB.
\end{abstract}




\begin{tabular}{l} 
ARTICLE INFO \\
\hline Keywords: \\
Cognitive development; \\
games; kindergarten; play \\
method; puzzle \\
How to cite: \\
Mu'min, S. A., \& Yultas, \\
N. S. (2019). Efektifitas \\
Penerapan Metode \\
Bermain dengan Media \\
Puzzle dalam \\
Meningkatkan \\
Kemampuan Kognitif \\
Anak. Al-Ta'dib:Jurnal \\
Kajian Ilmu Kependidikan, \\
12(2), 226-239. \\
DoI: \\
http://dx.doi.org/10.31332/ \\
atdbwv12i2.1217
\end{tabular}

\begin{abstract}
This classroom action research aims to find out and describe the effectiveness of the application of games with puzzles in improving cognitive abilities of kindergarten students. Using observation and assessment, this research was conducted in two cycles, each consists of planning, implementation, observation and reflection. Descriptive analysis indicates that the use of puzzle is effective in increasing students' cognitive abilities gaining $75 \%$ of the assessment and categorized as developing as expected. The initial test shows that classically the students' ability is $36 \%$ in the criteria of developing as expected. The classical success in cycle 1 is of $55 \%$ in very well-developing category and $45 \%$ developing as expected. In the second cycle, students' cognitive development increased to $82 \%$, in the criteria of developing as expected and $18 \%$ were in the very well-developing criteria.
\end{abstract}

\section{Pendahuluan}

Taman Kanak-Kanak (TK) merupakan lembaga pendidikan yang memberikan layanan pendidikan kepada anak usia dini pada rentangan usia 4-6 tahun. Pendidikan anak usia dini TK memiliki peran yang cukup besar untuk mengoptimalkan kemampuan anak dan penanaman nilai-nilai agama dan moral pada anak. Undang-undang Nomor 20 Tahun 2003 tentang sistem Pendidikan Nasional Pasal 1 angka 14 menyatakan bahwa pendidikan anak usia dini (PAUD) adalah suatu upaya pembinaan yang ditujukan kepada anak sejak lahir sampai dengan usia enam tahun. Terdapat berbagai jenis layanan perlindungan anak usia dini untuk usia 0 sampai 6 tahun sesuai dengan kondisi dan kemampuan yang ada baik dalam jalur pendidikan formal maupun nonformal. Penyelenggaran PAUD jalur pendidikan formal berbentuk taman kanak-kanak (TK), raudhatul athfal (RA) dan bentuk lainnya yang sederajat, yang menggunakan program untuk anak usia 4-6 tahun.

Metode pembelajaran di TK dilakukan sesuai dengan karakteristik perkembangan anak. Anak usia TK memiliki kecenderungan bermain sambil belajar sehingga metode bermain dianggap tepat dalam proses pembelajarannya. Metode bermain dapat dilakukan di dalam maupun di luar kelas. Agar metode bermain bisa berlangsung optimal, maka dibutuhkan media permainan yang sesuai dengan tema pembelajaran. Selain menimbulkan rasa senang pada anak-anak, metode bermain biasanya 
dilakukan dengan berkelompok agar tercipta interaksi yang lebih intensif antara anak yang satu dengan yang lain. Melalui kerja kelompok dan interaksi sosial diharapkan dapat membantu meningkatkan kemampuan kognitif anak. Keragaman metode pembelajaran yang diterapkan dalam pembelajaran di TK menjadi hal yang penting diperhatikan oleh guru agar pembelajaran berlangsung menyenangkan. Metode bermain merupakan salah satu metode yang tepat diterapkan di TK mengingat anak berada pada masa bermain. Bermain merupakan suatu kegiatan yang dapat merangsang perkembangan kognitif anak.

Berdasarkan observasi awal yang dilakukan di TK Iklal Matabondu Desa Lalonggaluku Timur Kabupaten Konawe belum terlihat tercapainya perkembangan kognitif anak dalam hal memecahkan masalah dalam permainan. Hasil pengamatan awal menunjukkan bahwa guru masih lebih sering memberikan tugas menulis dan belum menerapkan metode pembelajaran sambil bermain. Selain itu, kemampuan guru merancang media yang dapat merangsang anak dalam memecahkan masalah masih terbatas. Kondisi ini bisa menyebabkan keterbatasan berpikir dan berimajinasi pada anak. Untuk mengembangkan kemampuan kognitif anak di TK Iklal Matabondu, peneliti menggunakan permainan puzzle. Sebelumnya, penerapan permainan puzzle di TK Iklal Matabondu masih belum maksimal karena dalam proses pembelajaran, puzzle digunakan hanya sesekali saja dan lebih sering menggunakan papan tulis dalam proses belajar mengajar.

Kemampuan kognitif dapat dipahami sebagai kemampuan anak untuk berpikir lebih kompleks serta kemampuan melakukan penalaran dan pemecahan masalah. Dalam perkembangannya, kemampuan kognitif akan memudahkan peserta didik menguasai pengetahuan umum yang lebih luas sehingga anak mampu melanjutkan fungsinya dangan wajar dalam interaksinya dengan masyarakat dan lingkungan. Menurut Vygotsky dalam Desmita (2009), kemampuan kognitif anak dapat dibantu melalui interaksi sosial. Menurutnya kognitif anak tumbuh tidak hanya melalui tindakan terhadap objek, melainkan juga oleh interaksi dengan orang dewasa dan teman sebayanya.

Selanjutnya Beaty dalam Aisyah (2014) mengemukakan bahwa ada lima program pengembangan kognitif pada anak usia dini, yaitu: bentuk, warna, ukuran, pengelompokan, dan pengurutan. Bentuk adalah salah satu konsep dari konsep paling awal yang harus dikuasai. Anak dapat membedakan benda berdasarkan bentuk lebih dulu sebelum berdasarkan ciri lainnya. Warna paling baik dikembangkan dengan cara memperkenalkan warna satu-persatu kepada anak dan menawarkan beragam permainan dan kegiatan menarik yang berhubungan dengan warna. Ukuran adalah salah satu yang diperlihatkan anak secara khusus. Sering kali hubungan ukuran ini diajarkan dalam konteks kebalikan, seperti besar dan kecil, panjang dan 
pendek, dan sebagainya. Dalam pengelompokan, anak memilih benda, orang, kejadian, atau ide dalam kelompok dengan dasar beberapa karakteristik umum, seperti warna, ukuran atau bentuk. Terakhir, pengurutan adalah kemampuan meletakkan benda dalam urutan menurut urutan tertentu.

Permainan sebaiknya diberikan sebagai fasilitas media pembelajaran yang sekiranya membuat anak merasa senang, bebas, dan tidak terganggu seiring dengan pendapat Hurlock dalam Suyadi (2010) yang menyatakan bahwa permainan adalah akitivitas-aktivitas untuk memperoleh kesenangan. Permainan identik dengan dunia anak, dengan permainan anak beraktifitas dan bersosialisasi dengan lingkungan. Permainan dapat menumbuhkan imajinasi dan kreativitas anak sesuai dengan tingkat perkembangannya. Melalui permainan, anak mendapatkan pengalaman, pengetahuan dan keterampilan. Dalam prakteknya, banyak cara untuk melakukan kegiatan permainan tersebut. Ada yang menggunakan media alat ada juga yang tidak. Pada dasarnya setiap kegiatan permainan membawa dampak positif terhadap perkembangan anak. Menurut Zulkifli (2006) permainan adalah kesibukan yang dipilih sendiri tanpa ada unsur paksaan, tanpa didesak oleh rasa tanggung jawab. Permainan membuat anak semakin lincah mengenal objek (benda) yang dapat dilihat dan dipegangnya. Salah satu permainan anak yang juga dapat menjadi media belajar yaitu permainan puzzle.

Menurut Julianti (2014) puzzle merupakan permainan yang membutuhkan kesabaran dan ketekunan anak dalam merangkainya. Puzzle merupakan kepingan tipis yang terdiri atas 5-10 atau lebih potongan yang terbuat dari kayu atau lempengan karton dengan warna gambar yang jelas dan bentuk serta ukuran papan sederhana. Anak yang terbiasa bermain puzzle akan terlatih untuk terbiasa tenang, tekun dan sabar dalam menyelesaikan sesuatu. Kepuasan yang didapat anak saat menyelesaikan puzzle merupakan salah satu pembangkit motivasi anak untuk hal-hal yang baru.

Menurut Soebachman (2012) permainan puzzle adalah permainan yang terdiri atas kepingan-kepingan dari satu gambar tertentu yang dapat melatih kreaktivitas, keteraturan, dan tingkat konsentrasi. Permainan puzzle dapat dilakukan oleh anak-anak hingga anak belasan tahun, tetapi tentu saja tingkat kesulitannya harus disesuaikan dengan usia anak yang memainkannya. Saat bermain puzzle anak akan mencoba memecahkan masalah yaitu menyusun gambar. Pada tahap awal mengenal puzzle, mereka mungkin mencoba menyusun gambar puzzle dengan cara mencoba memasang bagian-bagian puzzle tanpa petunjuk. Saat bermain puzzle dengan sedikit arahan dan contoh, maka anak sudah dapat mengembangkan kemampuan kognitifnya dengan cara mencoba menyesuaikan bentuk, warna, atau logika. Menurut Rani (2014) puzzle adalah permainan menyusun dan mencocokkan bentuk dan tempatnya sesuai dengan gambar yang sebenarnnya. Permainan puzzle adalah bagian-bagian gambar yang disatukan menjadi satu dan dapat 
mengembangkan kemampuan kognitif anak dengan cara menyesuaikan warna, logika dan bentuk dan membantu anak untuk belajar memecahkan masalah.

Selanjutnya, menurut Levina (2004) ada beberapa bentuk golongan puzzle, yaitu puzzle rakitan (construction puzzle) berupa kumpulan potonganpotongan yang terpisah, yang dapat digabungkan kembali menjadi beberapa bentuk sederhana berwarna-warni. Mainan rakitan ini sesuai untuk anak yang suka bekerja dengan tangan, suka memecahkan puzzle, dan suka berimajinasi. Selanjutnya, puzzle batang berupa permainan teka-teki matematika sederhana namun memerlukan pemikiran kritis dan penalaran yang baik untuk menyelesaikannya. Puzzle batang ada yang dimainkan dengan cara membuat sesuai yang kita inginkan ataupun menyusun gambar yang terdapat pada batang puzzle. Puzzle lantai terbuat dari bahan sponge (karet/busa) sehingga baik untuk alas bermain anak dibandingkan harus bermain di atas keramik. Puzzle lantai memiliki desain yang sangat menarik dan tersedia banyak pilihan warna yang cemerlang, juga dapat merangsang kreaktivitas dan melatih kemampuan berpikir anak. Puzzle lantai sangat mudah dibersihkan dan tahan lama. Puzzle angka bermanfaat untuk mengenalkan angka. Selain itu anak dapat melatih kemampuan berpikir logisnya dengan menyusun angka sesuai urutannya. Selain itu, puzzle angka berfungsi untuk melatih koordinasi mata dengan tangan, melatih motorik halus serta menstimulasi kerja otak. Puzzle transportasi merupakan permainan bongkar pasang yang memiliki gambar berbagai macam kendaraan darat, laut dan udara. Fungsinya selain untuk melatih motorik anak, juga untuk stimulasi otak kanan dan otak kiri. Anak akan lebih mengetahui macam-macam kendaraan. Selain itu anak akan lebih kreatif, imajinatif, dan cerdas. Puzzle logika merupakan puzzle gambar yang dapat mengembangkan keterampilan serta anak akan berlatih untuk memecahkan masalah. Puzzle ini dimainkan dengan cara menyusun kepingan puzzle hingga membentuk suatu gambar yang utuh. Puzzle geometri merupakan puzzle yang dapat mengembangkan keterampilan mengenali bentuk geometri (segitiga, lingkaran, persegi dan lain- lain), selain itu anak akan dilatih untuk mencocokkan kepingan puzzle geometri sesuai dengan papan puzzlenya.

Permainan puzzle bisa memberikan kesempatan belajar yang banyak kepada anak. Manfaat permainan puzzle menurut Rani (2014) adalah mengasah otak, melatih koordinasi mata dan tangan, melatih membaca, melatih nalar, melatih kesabaran, dan memberikan pengetahuan. Puzzle bermanfaat untuk mengasah otak karena kecerdasan otak anak akan terlatih saat bermain puzzle dengan aktifnya sel-sel otak untuk memecahkan masalah. Puzzle berguna untuk melatih koordinasi mata dan tangan dikarenakan anak harus mencocokkan kepingan-kepingan puzzle dan menyusunnya menjadi satu gambar utuh. Puzzle bermanfaat untuk melatih 
membaca, membantu mengenal bentuk dan langkah penting menuju pengembangan keterampilan membaca. Puzzle berguna untuk melatih nalar melalui permainan puzzle dalam bentuk manusia, misalnya, akan melatih nalar anak-anak karena mereka akan menyimpulkan di mana letak kepala, tangan, kaki dan lain-lain sesuai dengan logika. Puzzle dapat melatih kesabaran. Selain itu, puzzle dapat memberikan pengetahuan kepada anakanak untuk mengenal warna dan bentuk. Anak juga akan belajar konsep dasar binatang, alam sekitar, jenis-jenis benda, anatomi tubuh manusia, dan lain-lain.

Agar guru dapat mengetahui kemampuan anak dalam bermain puzzle, maka guru harus menggunakan puzzle dengan berbagai macam tingkat kesulitan. Menurut Sachiyo dalam Sudono (2000) tingkat kesulitan puzzle terdiri atas 3 golongan, yaitu: a) golongan tingkat mudah (terdiri atas 4-5 potongan); b) golongan tingkat sedang (terdiri atas 6-10 potongan); dan, c) golongan tingkat sulit (terdiri atas 15-30 potongan). Menurut Zaman (2014) langkah-langkah bermain puzzle, yaitu: a) memperlihatkan gambar puzzle sebagai kesatuan; b) mengeluarkan gambar-gambar tersebut menjadi bagianbagian; c) menyusun kembali gambar sesuai dengan lekuk-lekukan yang sudah ada di papan dasar; d) mengajak anak untuk mencoba menyusun puzzle; dan (e) memberi kesempatan anak untuk menyusun puzzle.

Berdasarkan penelitian Ilma (2016) yang berjudul terkait penerapan media puzzle untuk meningkatkan kemampuan kognitif anak TK, penggunaan media puzzle meningkatkan kemampuan kognitif anak. Dalam hasil penelitiannya ditemukan pada peningkatan dari siklus 1 ke siklus 2 dengan persentase rata-rata sebesar $76,7 \%$ ke $86 \%$. Sejalan dengan itu, Saropah (2015) yang melakukan penelitian terkait penggunaan puzzle untuk melihat dampaknya terhadap kemampuan kognitif anak PAUD, khususnya dalam mengenal urutan angka 1-10 umur 4-5 tahun, menyimpulkan bahwa media puzzle dapat mengembangkan kemampuan kognitif anak dengan adanya persentase rata-rata $80 \%$.

\section{Metode Penelitian}

Jenis penelitian ini adalah penelitian tindakan kelas (classroom action research) model Kemmis dan Taggart (Arikunto, 2000) yang dilakukan dalam 2 siklus. Penelitian ini dilaksanakan di TK Iklal Matabondu di Desa Lalonggaluku Timur, Kecamatan Bondoala, Kabupaten Konawe, pada kelompok B yang berjumlah 11 anak dengan rincian 5 perempuan dan 6 lakilaki dengan usia rata-rata 5-6 tahun. Objek dalam penelitian ini adalah seluruh proses pelaksanaan kegiatan meningkatkan kemampuan kognitif anak melalui permainan menyusun puzzle pada anak kelompok B TK Iklal 
Matabondu. Masing-masing siklus dengan tahapan perencanaan, pelaksanaan, observasi dan refleksi.

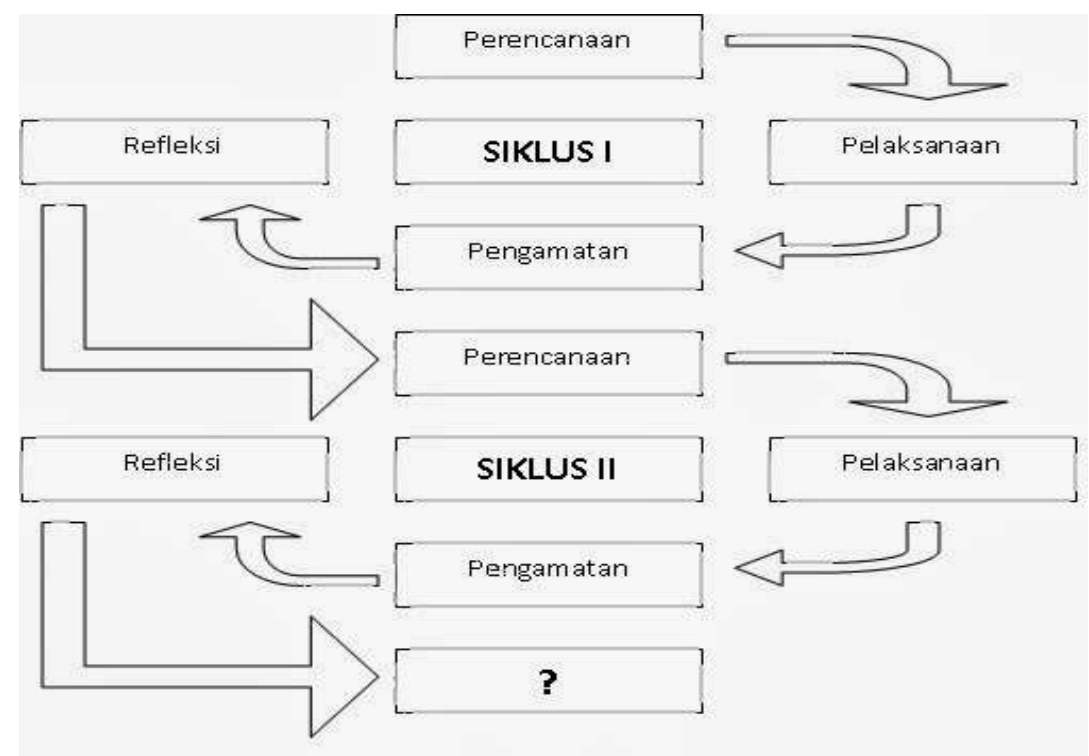

Gambar 1 Bagan siklus penelitian tindakan kelas

Faktor yang diselidiki pada penelitian ini adalah faktor anak yakni peningkatan kemampuan kognitif anak melalui permainan puzzle dan faktor guru yakni bagaimana guru mempersiapkan dan melaksanakan pembelajaran. Pada tahapan pelaksanaan guru melaksanakan kegiatan pembelajaran sesuai dengan yang telah direncanakan dengan menggunakan RPPH dengan kegiatan bermain. Puzzle yang digunakan adalah puzzle yang terbuat dari kertas, kardus, dan gabus kecil dan dengan gambar puzzle yang disesuaikan dengan tema pelajaran. Puzzle yang digunakan yaitu puzzle dengan tingkat mudah, sedang dan sulit. Adapun langkah-langkah yang digunakan dalam penyusunan puzzle yaitu anak diminta memperhatikan gambar puzzle sebagai suatu kesatuan, melepaskan kepingan puzzle dari papannya, mengacak kepingan puzzle tersebut, menyusun kembali gambar tersebut sesuai dengan lekuk-lekukan yang sudah ada di papan dasar, dan terakhir menyusun puzzle.

Data yang diperoleh dikumpulkan melalui observasi, dokumentasi, dan penilaian. Seluruh data yang diperoleh dianalisis secara deskriptif guna mengetahui keberhasilan kegiatan ini pada setiap siklus. Indikator keberhasilan anak dalam penelitian tindakan kelas ini adalah kemampuan kognitif anak. Proses pembelajaran dikatakan berhasil jika anak sudah 
mampu menyusun puzzle secara utuh dan benar, tanpa bantuan orang lain. Anak dikatakan berhasil apabila hasil penilaian telah mencapai $75 \%$ dan minimal memperoleh bintang 3 ( $\star \star \star *)$ Berkembang Sesuai Harapan (BSH).

\section{Hasil dan Pembahasan}

Berdasarkan perencanaan tindakan yang dilakukan maka penelitian ini diawali dengan kegiatan tes awal yang bertujuan untuk mengetahui dan memperoleh gambaran mengenai kemampuan kogntif anak. Anak diminta untuk menyusun puzzle yang disiapkan kemudian peneliti mengamati aktivitas anak. Berdasarkan hasil tes awal diketahui ada 4 anak (36\%) yang berada pada taraf kategori Berkembangn Sesuai Harapan (BSH), sedangkan 7 anak (64\%) berada pada kategori Mulai Berkembang (MB) dan Belum Berkembang (BB). Hasil tersebut menunjukkan bahwa kemampuan kognitif anak didik masih rendah. Hasil tersebut dijadikan dasar untuk melakukan tindakan selanjutnya. Kegiatan penelitian ini dilaksanakan sebanyak dua siklus dimana setiap siklus diadakan dua kali pertemuan.

\subsection{Pelaksanaan Tindakan Siklus I}

Tindakan siklus I terdiri atas dua kali pertemuan, pertemuan pertama dilaksanakan pada hari Senin 23 April 2018 dan pertemuan kedua dilaksanakan pada hari Selasa 24 April 2018. Di siklus I pertemuan 1, guru mengajarkan tema binatang, subtema binatang kesayangan, dan tema spesifik binatang kelinci dan menggunakan puzzle dengan golongan puzzle tingkat mudah yang terdiri atas 6 kepingan puzzle. Kegiatan awal proses pembelajaran diawali dengan masuk kelas, mengucapkan salam, bernyanyi dan membaca doa. Setelah itu, guru menjelaskan permainan puzzle, cara menyusun puzzle, waktu proses kegiatan belajar berlangsung, dan memberikan motivasi belajar kepada anak didik. Sebelum masuk kegiatan inti, guru memberikan apersepsi sesuai dengan tema hari itu yaitu binatang dengan subtema binatang kesayangan. Setelah apersepsi, guru memperlihatkan media yang digunakan yaitu permainan puzzle dan selanjutnya guru memperagakan cara bermain menyusun puzzle.

Kegiatan selanjutnya adalah meminta anak didik melakukan kegiatannya. Selama proses kegiatan pembelajaran berlangsung, peneliti dan kolaborator mengamati dan mencatat perkembangan kognitif anak yang sedang melakukan kegiatan menyusun permainan puzzle. Dari kegiatan yang dilaksanakan di siklus pertama ditemukan bahwa sebagian anak sudah bisa bermain puzzle dengan baik walaupun masih belum sesuai dengan apa yang diharapkan. 
Di siklus I pertemuan 2, guru mengajarkan tema binatang, subtema binatang besar dengan tema spesifik gajah. Pada pertemuan kedua ini puzzle yang digunakan adalah puzzle dengan tingkat kesulitan sedang dengan jumlah keping 10 yang terbuat dari kardus bekas. Pada pertemuan 2 ini, tampak anak-anak sudah memulai menyelesaikan permainan puzzle tanpa bantuan orang lain, namun masih ada pula yang sering meminta guru untuk membantunya dalam menyelesaikan permainan menyusun puzzle.

Puzzle yang digunakan pada pertemuan 1 dalam siklus pertama adalah puzzle yang terbuat dari kertas HVS. Kelemahan media ini yaitu mudah robek karena terbuat dari kertas. Selain itu, untuk meyusunnya menjadi puzzle yang utuh harus menggunakan lem. Karena peneliti melihat adanya kelemahan dari penggunaan media di pertemuan 1 siklus pertama ini maka peneliti mengganti media puzzlenya. Pada pertemuan 2, media puzzle yang digunakan yaitu puzzle yang terbuat kardus dan perekatnya menggunakan doubletape. Media puzzle yang terbuat dari kardus memiliki kelebihan tidak mudah robek dan tahan lama.

Selama pelaksanaan pembelajaran siklus I dan II, observer melakukan pengamatan terhadap proses kegiatan pembelajaran. Observasi tersebut menggunakan lembar observasi aktivitas guru dan lembar observasi aktivitas anak didik untuk mengetahui kesesuaian antara rencana tindakan dan pelaksanaan tindakan. Adapun penilaian pada setiap anak didik diberi simbol bintang $1(\star)=$ Belum Berkembang (BB), simbol bintang $2(\star \star)$ = Mulai Berkembang (MB), simbol bintang $3(\star \star \star)=$ Berkembang Sesuai Harapan (BSH), dan simbol bintang $4(\star \star \star \star)=$ Berkembang Sangat Baik (BSB). Hasil analisis data menunjukkan bahwa dari 11 anak yang mengikuti kegiatan tersebut, siswa yang mencapai KKM sebanyak 6 orang. Selanjutnya, secara klasikal rata-rata perolehan nilai kemampuan kognitif

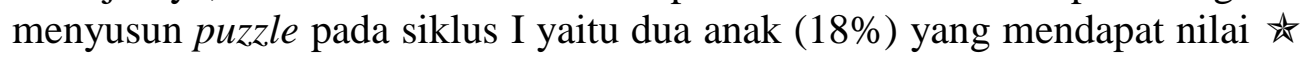
atau kategori Belum Berkembang (BB), tiga anak (27\%) mendapat $\star \star$ atau kategori Mulai Berkembang, enam anak (55\%) memperoleh $\star \star \star$ atau kategori Berkembang Sesuai Harapan (BSH), dan belum ada yang memperoleh $\star \star \star \star$ atau kategori berkembang sangat baik (BSB).

Kemampuan kognitif anak nampak ketika anak banyak bertanya terkait gambar dan bagaimana menyusun gambar puzzle. Semakin banyak anak bertanya semakin menunjukkan bahwa anak mulai berpikir. Ketika guru menjawab dan menjelaskan kembali cara menyusun gambar puzzle, anak mencoba mengingat-ingat jawaban guru dan menyusun puzzle seperti yang disampaikan guru. Hal ini menandakan bahwa kemampuan kognitif anak menunjukkan kemajuan.

Pada tahap refleksi, peneliti melakukan perbandingan menggunakan tabel observasi sebelum dilakukan tindakan dan setelah pelaksanaan tindakan di siklus I. Hasil refleksi mengungkapkan bahwa peningkatkan kemampuan 
kognitif anak dapat dilihat melalui persentase nilai yang diperoleh pada pratindakan. Peneliti bersama kolaborator mendiskusikan kegiatan yang telah dilaksanakan pada pertemuan pertama dan pertemuan kedua terkait hal-hal yang masih menjadi kendala pada siklus I sehingga menyebabkan belum tercapainya kriteria ketuntasan yang telah ditetapkan. Hasil refleksi mengungkap bahwa masalah yang terjadi di siklus ini adalah terkait media yang mudah rusak karena terbuat dari kertas HVS serta kombinasi warna yang kurang menarik. Selain itu, masih ada anak-anak yang selalu meminta bantuan guru untuk menyelesaikan tugasnya serta manajemen waktu yang tidak terkontrol. Berdasarkan diskusi dengan kolaborator maka perlu dilakukan perbaikan-perbaikan untuk siklus berikutnya terkait media dan manajemen kelas. Media diganti dari bahan kardus sehingga tidak mudah rusak dan sobek dan warna-warna gambar puzzle dibuat lebih cerah didominasi warna merah, hijau, kuning, dan biru. Terkait penanganan kegiatan di kelas, anak-anak lebih diarahkan untuk bisa menyelesaikan tugasnya sendiri dengan manawarkan hadiah bintang ganda. Melihat kekurangan yang ada serta kemampuan kognitif anak secara klasikal pada tindakan siklus I yang belum memenuhi indikator keberhasilan yang ditetapkan dalam penelitian ini, maka peneliti dan kolaborator bersepakat bahwa penelitian ini dilanjutkan pada siklus II.

\subsection{Pelaksanaan Tindakan Siklus II}

Tindakan siklus II terdiri atas dua kali pertemuan, pertemuan pertama dilaksanakan pada hari Senin 7 Mei 2018 dan pertemuan kedua dilaksanakan pada hari Selasa 8 Mei 2018. Pada siklus II pertemuan 1, guru mengajarkan tema pekerjaan, subtema macam-macam pekerjaan, dengan tema dokter. Sebelum memulai kegiatan awal dalam proses pembelajaran, anak didik diminta duduk bersama dengan teman-temannya. Kegiatan awal proses pembelajaran diawali dengan mengajak anak masuk di dalam kelas, mengucapkan salam, berdoa dan bernyanyi, menjelaskan aturan dalam kegiatan bermain menyusun puzzle, menjelaskan aturan waktu proses kegiatan belajar berlangsung, dan memberikan motivasi belajar kepada anak didik.

Sebelum masuk kegiatan inti, guru memberikan apersepsi sesuai dengan tema hari itu yaitu profesi dokter. Setelah apersepsi, guru menjelaskan kegiatan yang akan dilaksanakan pada kegiatan inti. Anak-anak diminta untuk tenang dan menyimak kegiatan yang dilakukan, lalu guru memperlihatkan media yang digunakan yaitu permainan menyusun puzzle dokter. Selanjutnya, guru memeragakan cara menyusun puzzle. Puzzle yang digunakan dalam siklus II pertemuan 1 yaitu puzzle dengan golongan tingkat sulit dengan jumlah kepingan 12 potongan puzzle. Kegiatan selanjutnya 
adalah meminta anak didik melaksanakan kegiatannya. Selama proses kegiatan pembelajaran berlangsung, peneliti dan kolaborator mengamati dan mencatat perkembangan anak yang sedang melakukan kegiatan bermain menyusun puzzle. Dari kegiatan yang dilaksanakan di siklus II pertemuan 1 ini, kemampuan kognitif anak mulai menunjukkan peningkatan dari siklus sebelumnya karena anak sudah bisa menyusun puzzle dengan baik dan sesuai yang diharapkan.

Di siklus II pertemuan 2, guru mengajarkan tema pekerjaan, subtema macam-macam pekerjaan, dengan tema spesifik guru. Rangkaian kegiatan awal, kegiatan inti dan akhir selama proses pembelajaran serupa dengan pertemuan pertama. Pada pertemuan kedua, puzzle yang digunakan adalah golongan puzzle tingkat sulit dengan jumlah 16 keping puzzle dan terbuat dari gabus kecil. Kegiatan yang dilaksanakan pada siklus II sudah baik dan kemampuan kognitif anak sudah menunjukkan peningkatan yang terlihat dari banyaknya anak yang mampu menyelesaikan kegiatannya dan hanya sebagian saja yang membutuhkan bimbingan. Secara klasikal, rata-rata perolehan nilai kemampuan kognitif dalam menyusun puzzle siswa kelompok B berada pada kategori BSH, ketuntasan belajar pada siklus II sebesar $82 \%$ dengan kategori BSH dan persentase ketidaktuntasan mencapai $18 \%$ berada pada kategori MB.

Kegiatan pada siklus II berlangsung dengan tertib dan menyenangkan dan kemampuan kognitif anak nampak mengalami peningkatan dibandingkan dengan siklus sebelumnya. Berdasarkan hasil observasi yang diperoleh dari tindakan siklus II, kekurangan yang ada pada siklus II, media gambar puzzle yang bermasalah karena terbuat dari kertas telah diganti dengan puzzle berbahan kardus, demikian pula variasi warna gambar yang lebih cerah membuat anak-anak bersemangat dan menyukai puzzle-nya. Anak-anak terlihat gembira dengan media yang lebih bagus. Belajar dengan bergembira membantu anak mengembangkan kemampuan kognitif menjadi lebih baik dari siklus sebelumnya. Media puzzle yang digunakan pada siklus II adalah puzzle yang terbuat dari gabus kecil yang ditempelkan pada kardus. Kelebihan dari media ini, yaitu: tahan lama, tidak mudah rusak, dan aman bagi anak-anak.

Persentase keberhasilan kemampuan kognitif anak telah mencapai indikator keberhasilan yaitu anak yang berada pada kriteria BSB sebanyak sembilan orang atau sebanyak $82 \%$. Hasil tersebut telah memenuhi indikator keberhasilan penelitian tindakan kelas yang menjadi acuan peneliti yaitu $75 \%$. Oleh karena itu, peningkatan kemampuan kognitif anak melalui metode bermain menyusun puzzle pada kelompok B TK Iklal Matabondu tidak perlu dilanjutkan lagi ke siklus selanjutnya. Pada tahap ini, anak sudah memiliki ide sendiri untuk menyusun puzzle-nya karena anak sudah tidak banyak meminta bantuan guru. Pada tahap ini pula, kemampuan anak 
mengingat instruksi guru juga sudah nampak yang terlihat dari kemampuan anak menjawab dengan lancar ketika guru bertanya.

\subsection{Efektifitas Media Puzzle dan Peningkatan Kemampuan Kognitif Anak}

Penelitian tindakan kelas dengan metode menyusun puzzle adalah upaya untuk meningkatkan kemampuan kognitif anak melalui metode bermain menyusun puzzle pada anak kelompok B di TK Iklal Matabondu Kecamatan Bondoala, Kabupaten Konawe. Upaya dalam penelitian ini didasarkan atas hasil observasi yang dilakukan sebelumnya yang menunjukkan rendahnya kemampuan kognitif anak. Penelitian dilaksanakan dalam dua siklus yang dilakukan oleh peneliti dengan berkolaborasi bersma guru kelompok B. Tiap siklus dilakukan dengan tahapan perencanaan, pelaksanaan tindakan, observasi, dan refleksi.

Hasil observasi aktivitas guru siklus I pertemuan 1 dan pertemuan 2 menunjukkan guru telah melakukan kegiatan pembelajaran sesuai dengan rencana kegiatan bermain menyusun puzzle, namun masih ada beberapa aspek yang belum terlaksana seperti guru tidak mengajak anak melakukan kegiatan motorik kasar dan guru tidak meminta anak untuk menceritakan kegiatan hari tersebut. Hal ini dikarenakan guru belum bisa mengolah waktu dengan baik sehingga hasil persentase keberhasilan mengajar guru hanya mencapai $60 \%$.

Hasil observasi aktivitas anak di siklus I menunjukkan bahwa aktivitas anak telah berada pada kategori aktif dengan persentase $86 \%$. Kondisi awal kemampuan kognitif anak masih belum berkembang dengan baik, yang ditunjukkan dengan persentase ketuntasan 36\%. Oleh karena itu, kemampuan anak dalam menyusun puzzle perlu dikembangkan karena kemampuan ini merupakan hal yang mendasar bagi kesiapan anak untuk menyelesaikan masalah saat menemukan masalah dalam permainan.

Kegiatan bermain puzzle dalam penelitian ini selain menarik dan menyenangkan, juga dikaitkan dengan nilai-nilai pendidikan karakter agar kemampuan kognitif anak meningkat dengan baik. Nilai pendidikan karakter tersebut diantaranya adalah jujur, toleransi, displin, mandiri, bersahabat/komunikatif, rasa ingin tahu dan tanggung jawab. Hal ini sesuai dengan ketentuan pemerintah tentang 18 nilai karakter yang yang harus ditanamkan kepada anak-anak.

Hasil observasi aktivitas guru di siklus II menunjukkan bahwa guru telah melakukan tindakan pengajaran sesuai dengan rencana kegiatan pembelajaran. Hal tersebut berdasarkan rata-rata aktivitas guru di siklus II pertemuan 1 dan 2 sebesar 95\% atau berada pada kategori sangat aktif. Selain itu, kemampuan kognitif anak mengalami peningkatan yaitu sebanyak 9 orang anak didik yang mencapai KKM dari 11 anak atau sebanyak $82 \%$ 
berada pada kriteria BSB dan Berkembang Sesuai Harapan BSH. Hanya dua anak yang tidak mencapai KKM dengan kriteria MB.

Penelitian ini tampak memberikan manfaat bagi anak terutama dalam pengembangan kemampuan kognitif mereka. Hal ini terlihat dari tingkat peningkatan kemampuan anak yang diukur melalui tes awal sebesar 36\%, pada siklus 1 dan sebesar 55\%, dan pada siklus II meningkat menjadi 82\%. Hal ini menunjukkan kemampuan kognitif mengalami peningkatan sebanyak $46 \%$.

\section{Kesimpulan}

Dari hasil penelitian ini dapat disimpulkan bahwa metode permainan menyusun puzzle dapat membawa perubahan pada kemampuan kognitif anak di TK Iklal Matabondu. Keberhasilan klasikal pada siklus I mengalami peningkatan setelah di siklus II sehingga sebagian besar anak didik berada pada kriteria Berkembang Sesuai Harapan (BSH) dan Berkembang Sangat Baik (BSB). Penelitian dihentikan sampai siklus II karena sudah memenuhi kriteria keberhasilan indikator yaitu minmal 75\% anak rata-rata kemampuan kognitif berada pada kategori BSH, artinya anak sudah mampu mengerjakan dan menyelesaikan kegiatan atau tugas yang diberikan dengan bimbingan tetapi secara tidak langsung. Penelitian ini mengindikasikan bahwa metode permainan menyusun puzzle bisa menjadi bahan pertimbangan oleh guruguru PAUD dan TK karena selain menyenangkan bagi anak, kegiatan ini bisa merangsang perkembangan kognitif mereka.

\section{Daftar Pustaka}

Aisyah, S., Amini, M., Chandrawati, T., \& Novita, D. (2014). Perkembangan dan konsep dasar anak usia dini. Jakarta: Universitas Terbuka.

Arikunto, S. (2000). Manajemen penelitian. Jakarta: Rineka Cipta.

Desmita. (2009). Psikologi perkembangan peserta didik. Bandung: Remaja Rosdakarya.

Julianti. (2014). Penerapan media game Puzzle untuk meningkatkan keaktifan siswa kelas VII SMP Negeri Malang. Malang: IKIP Budi Utomo.

Levina. (2004). A mind at a time. Jakarta: Gramedia Pustaka. 
Rani, Y. (2014). Permainan yang meningkatkan kecerdasaan anak. Jakarta: Niaga Swadaya.

Ilma, R. (2016). Penerapan media game puzzle untuk meningkatkan kemampuan kognitif anak kelompok Al dalam mengenal bilangan di TK Dharma Wanita Grenden Puger Kabupaten Jember Tahun Pelajaran 2015/2016. Skripsi tidak dipublikasi. Jember: Universitas Jember.

Saropah, S. (2018). Meningkatkan kemampuan kognitif dalam mengenal urutan angka 1-10 melalui permainan puzzle pada anak umur 4-5 tahun. http://simki.unpkediri.ac.id, di akses pada 6 Februari 2018.

Soebachman, A. (2012). Pemainan asyik bikin anak pintar. Yogyakarta: IN AzNaBooks.

Sudono. (2000). Sumber belajar dan alat permainan untuk anak usia dini. Jakarta: Grasindo.

Suyadi. (2010). Psikologi belajar pendidikan anak usia dini. Yogyakarta: Bintang Pustaka Abadi.

Undang-Undang Nomor 20 tahun 2003 Bab 1 Pasal 1 Ayat 14.

Zaman, B. (2014). Media dan sumber belajar TK. Jakarta: Universitas Terbuka.

Zulkifli. (2006). Psikologi perkembangan. Bandung: Remaja Rosdakarya. 